\title{
Developing Corporate Governance Index for Vietnamese Banking System
}

\author{
Tran Thi Thanh Tu${ }^{1}$, Pham Bao Khanh ${ }^{2}$ \& Phung Duc Quyen ${ }^{3}$ \\ ${ }^{1}$ VNU University of Economics and Business, Hanoi, Vietnam \\ ${ }^{2}$ Deposit Insurance of Vietnam, Ha Noi, Vietnam \\ ${ }^{3}$ Vietnam Bond Market Association Bond Association, Vietnam \\ Correspondence: Tran Thi Thanh Tu, VNU University of Economics and Business, Hanoi, Vietnam. E-mail: \\ tuttt@vnu.edu.vn
}

Received: March 14, 2014

Accepted: April 6, $2014 \quad$ Online Published: April 7, 2014

doi:10.5430/ijfr.v5n2p175

URL: http://dx.doi.org/10.5430/ijfr.v5n2p175

\begin{abstract}
The purpose of this paper is twofold. Firstly, we propose a specific method with a detailed questionnaire with 60 questions, divided into five main components: Shareholders and general shareholders' meeting; Board of directors; Supervisory board; Disclosure and transparency, auditing and Violations. Second, the method will then be applied to calculate the CGI for 40 Vietnamese commercial banks in three years 2010, 2011 and 2012. To our best knowledge, this is the first time that a questionnaire has been designed and applied to construct the CGI for the Vietnamese banking sector. And thirdly, statistical analysis has been performed to examine the characteristics of the results obtained from the questionnaire.
\end{abstract}

Keywords: corporate governance, Vietnamese banking, index

\section{Introduction}

Corporate Governance can be defined as the system used to manage and control firms; it consists of a set of market and regulatory mechanisms which indicate how to manage accompany, including the relationships among different stakeholders and the objectives of the company.

Research has demonstrated that financial institutions are critically important for economic growth and efficient capital allocation of the economy. In the rapidly growing economies of Vietnam, as in many other emerging markets, banks are set to play a crucial role. It is, therefore, important to understand the key elements for maximizing the performance of banks and their role in the growing economies. While the corporate governance is deemed an important factor of bank operation, little effort has been put up to quantitatively identify the current quality of corporate governance in Vietnamese banks, and without this knowledge it is very difficult to improve the situation.

The most important contribution of our study is the design of a Corporate Governance Index (CGI) that can be used to measure the quality of Corporate Governance system in the Vietnamese banking system. There were researches conducted in corporate governance in Vietnamese enterprises as a whole but there were fewer researches for the banking sector; to our best knowledge, this is the first study that designs and applies method to measure the quality of corporate governance of 40 Vietnamese banks.

The CGI was constructed based on questionnaire which includes 60 questions divided into 5 categories: Shareholders and general shareholders' meeting; Board of directors; Supervisory board; Disclosure and transparency, auditing and Violations. CGI of 40 banks were calculated for 3 consecutive years $(2010-2012)$. The results show that the quality of corporate governance in Vietnamese banks over the past three years has not had any major changes as the Index fluctuates within the range of 41-44 (over the maximum score of 100). It is also found that listed banks have better corporate governance practices those non listed banks. And finally, banks with larger assets are found to have better quality of corporate governance than smaller banks.

\section{Literature Review}

The literature on constructing the Corporate Governance Index is vast. After having studied various researches in this field, the paper review literatures in notable aspects of methodology to build a CGI. 


\subsection{The General Procedure to Construct CGI}

Step 1: To study the relevant (international and domestic) regulations, standards, best practices that should be referred to in constructing the Index. These documents will serve as important benchmarks and guidelines to help the researchers determine if a company's corporate governance is good or not.

Step 2: To identify the sub-indices of the Corporate Governance Index. There are several components that form corporate governance of a company. Likewise, a CGI should be constructed from sub-indices corresponding to these components. This breakdown in CGI can also help researchers and practitioners better understand the nature of corporate governance in companies; hence take appropriate measures to improve it.

Step 3: Based on the regulations and standards studied in Step 1 and sub-indices identified in Step 2, the researchers will design a detailed questionnaire that can help to evaluate the quality of corporate governance in companies. The number of questions varies from one questionnaire to another, ranging from as few as 20 to more than 100 .

Step 4: To grade answers to the questionnaire designed in step 3 and calculating the index. If the answer indicates good corporate governance practice, the company will get higher score than when the answers indicate otherwise or vice versa (that is, the answer indicating good practice will get higher score than the one indicating bad practice). All the scores of the questions will then be added up to make the final Corporate Governance Index.

\section{Specifically, the notable issues in constructing the Corporate Governance Index include:}

\subsection{Popularly Studied, Referred to Regulations and Standards}

The overwhelming majority of researches refer to laws and regulations that companies have to comply with. The most popular ones are:

\section{- Law on Enterprise \\ - Law on Securities \\ - $\quad$ Law on Investment, Law on Foreign Investment \\ - The Stock Exchange's rules on stock listing and trading. \\ - Others}

The most commonly cited set of standards in the corporate governance literature is the "OECD Principles of Corporate Governance" (2004). The Basel Committee in 2010 published the "Principles for Enhancing Corporate Governance" as guidelines for enhancing corporate governance in the banking industry. The Financial Stability Board's "Principles for Sound Compensation Practices" in 2009 is also widely used while constructing CGI for banks and financial services firms.

In addition, each country often develops its own set of standard for corporate governance in accordance with their own laws and regulation. For example, Japan has the "Principles of Corporate Governance for Listed Companies" (2009), Malaysia has the "Malaysian Principles for Corporate Governance", India has the "Clause 49 of the Listing Agreement", ...

\subsection{Sub-indices of the Corporate Governance Index}

A CGI is often divided into several sub-indices representing specific aspects of companies' corporate governance (for example: Ananchotikul (2008), Sarkar J. et al(2012), Love and Rachinsky (2007), ... ). The following components are, more often than not, presented in constructing a CGI:

- Composition of the Board

- Responsibility of the Board

- $\quad$ Rights of shareholders

- Transparency and disclosure

- $\quad$ Audit committee

Besides, the following components are also quite popular:

- Ownership structure

- Conflict of interests

- Compensation policies 
- $\quad$ Related-parties transactions

\subsection{Methods Used to Collect Information}

Depending on the number and contents of questions, the researchers may choose to collect the necessary information to answer those questions either by sending the questionnaire to executives of companies and waiting for their responses or by collecting the information on their own through websites, Board Meeting minutes, Annual Reports, and other reports.

Collecting public information has a number of advantages over sending out questionnaires, such as:

- The sample will be more random and better represent the population since if the researchers send out the questionnaire, firms instantly believe that they are being judged on the appropriateness of their Corporate Governance structures. This may lead to the "self-selection phenomena" where only firms with good corporate governance structures will respond. This also helps increase the response rate.

- The researchers collecting public information on their own also avoid the problem of intentionally inaccurate reporting to overstate the companies' actual quality of corporate governance.

However, self-collecting information often seems to be a daunting task since the number of questions can be as many as more than 100 and the number of firms studied varies from about 50 to a few thousand. This, in turn, creates another problem. With that many questions and firms, it is inevitable that answers to some of the questions for some firms are just nowhere to be found. What should the researchers do in that case? Ananchotikul (2008) argues that since transparency and disclosure are important aspects of corporate governance and the fact that the companies choose not to disclose those information indicates that their corporate governance is inadequate, the scores they get will be as low as possible.

\subsection{The Number of Questions in the Questionnaire}

There are two contrary opinions on the suitable number of questions (and hence variables) in constructing a CGI. Most of researches, such as Love and Rachinsky (2007), Manawaduge (2012) or Ramlal (2011), agree that a large number of questions are necessary to depict corporate governance of companies. The number of questions in these researches range from about 30 to more than 100 .

A study which uses a different approach is the one performed by Bebchuk et al. (2008), who identify a subset of the 24 governance practices composing the G-Index which are significantly correlated with value. The authors build an "Entrenchment index" (E-index) using only 6 variables which are correlated with Tobin's Q and demonstrate that an increase in the index value (which corresponds to worse governance performances) is associated with sensibly negative extra-returns in the period from 1990 to 2003. They show that the remaining 18 variables are not correlated with firm value.

The authors argue against complex indexes which use a large number of variables, because many of them may not be correlated with value, or they are determined by other variables. They go further explaining that such complex indexes which include variables not correlated with value may be wrong measures of the quality of governance and that using them may induce firms to adopt counter-productive governance mechanisms (Monda and Giorgino, 2013).

\subsection{Question Types and Scores Assigned to Each Question}

Two types of question often used in constructing a CGI are the True/False questions and the multiple choice questions (MCQs). All studies employ True/False question. Especially Ramlal (2011), Ananchotikul (2008) and Cheung et al. (2005) use True/False questions only, no other types of question. True/False questions have the advantages of being simple, succinct and easy to score.

The majority of studies use both True/False questions and MCQs. MCQs can provide greater details and take into account more circumstances that can happen in real life.

The scoring method used for each type of questions also differs. For True/False questions, the score is often either 1 or 0. For MCQs, each choice will have the corresponding score; the scores are often within the [0-1] interval but sometimes the scores maybe negative or larger than 1.

For example, Love and Rachinsky (2007) provide the following options when they ask about the existence of a corporate governance code:

- A scoreof 0 if the company doesn't have the corporate governance code

- A score of 0.5 if the company is developing one; and 
- A score of 1 if the company has already had one.

In Tuteja and Nagpal (2013), the authors assign different scores to different questions, ranging from -2 to 5.

\subsection{Calculating Method}

The score of each question in the same group will be added up to form the sub-indices. The final CGI will be derived either by weighted or un-weighted averaging the sub-indices. The weighted average method is used when researchers believe that the components are not equally important and thus some sub-indices should have more weight than the others. On the contrary, other authors such as Manawaduge (2012) or Love and Rachinsky (2007) prefer the unweighted average because of its simplicity and that the authors do not have to make arbitrary or data-driven judgments on the relative importance of each attribute.

\section{Proposed Methodology to Construct a CGI for Vietnamese Banks}

Based on the above literature review and method for CGI of Vietnamese firms byT.N.Thang, 2010, OECD principles and Basel principles for enhancing corporate governance (2006), modifications from the innitially proposed methods by the authors in March 2012, following CGI construction method for banks is proposed.

A questionnaire with 60 questions covering 5 main categories has been designed. These categories are based on all principles of OECD which include: Shareholders and general shareholders' meeting, Board of directors, Supervisory board, Disclosure and transparency, auditing and Violations.Type and idea of each question and scoring scale aremainly based on questionaire of CGI for Vietnamese firms by T.N.Thang (2010). They are then modified so that they are in line with banking regulation such as the Law on credit institutions and regulation on management and organizations of Vietnamese banks in Viet Nam and Basel corporate governance recommendations.

Questions are designed to be straight forward and marked based on marking scale in Appendix 1. The maximum score is 100 . If banks are found to have any violation of regulations, their scores will be deducted accordingly

Table 1. Five main categories of the questionnaire

\begin{tabular}{lcc}
\hline Component & Number of questions & Maximum point \\
\hline Shareholders and general shareholders' meeting & 18 & 37 \\
\hline Board of directors & 20 & 34 \\
\hline Supervisory board & 8 & 8 \\
\hline Disclosure and transparency, auditing & 12 & 21 \\
\hline Violations & 2 & 0 \\
\hline
\end{tabular}

Source: The authors.

This questionnaire can be completed using public information and data of the bank including Annual Reports, Audited Financial Reports, Reports and other materials in general shareholders' meeting (GSM), other information from websites of the banks and other related websites. Discussions with investors and experts are also sources of information in some cases. The final CGI is the un-weighted average of the 5 sub-indices.

\section{Result of Vietnamese Bank's CGI}

\subsection{Results by Years}

The law on credit institutions took effect in January 2010 called for many changes in corporate governance. However, corporate governance index of Vietnam banks from 2010 to 2012 has been below average i.e. at 42/100, 42.7/100 and 43.3/100. This level of CGI suggests that there are many weaknesses in corporate governance of Vietnamese banks. While there is a slight improvement from 2010 to 2011, CGI in 2012 is unchanged as compared to 2011. The indication of this result is that the bank restructuring program of the Government started in 2011 has not brought about any obvious effect.

There is an upward trend in the mean over three years. However, both the ANOVA F-test and the Welch F-test cannot reject the null hypothesis that the means are equal at any conventional significance level. In other word, the changes over the years are not statistically significant. 


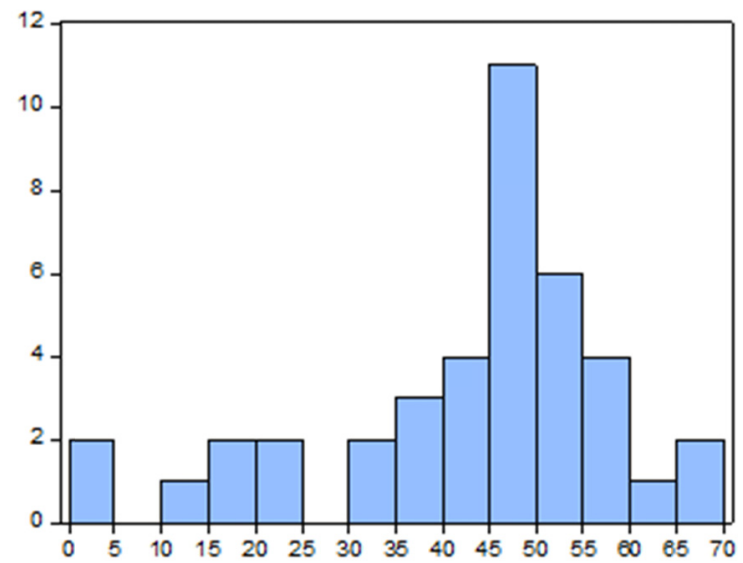

\begin{tabular}{|lr|}
\hline \multicolumn{2}{|l|}{ Series: TEN } \\
Sample 140 \\
Observations & 40 \\
& \\
Mean & 41.95000 \\
Median & 45.50000 \\
Maximum & 68.00000 \\
Minimum & 0.000000 \\
Std. Dev. & 16.01914 \\
Skewness & -1.022460 \\
Kurtosis & 3.710352 \\
& \\
Jarque-Bera & 7.810504 \\
Probability & 0.020136 \\
\hline
\end{tabular}

Figure 1. Histogram and descriptive statistics of CGI series by year

Figure 1a. CGI in 2010

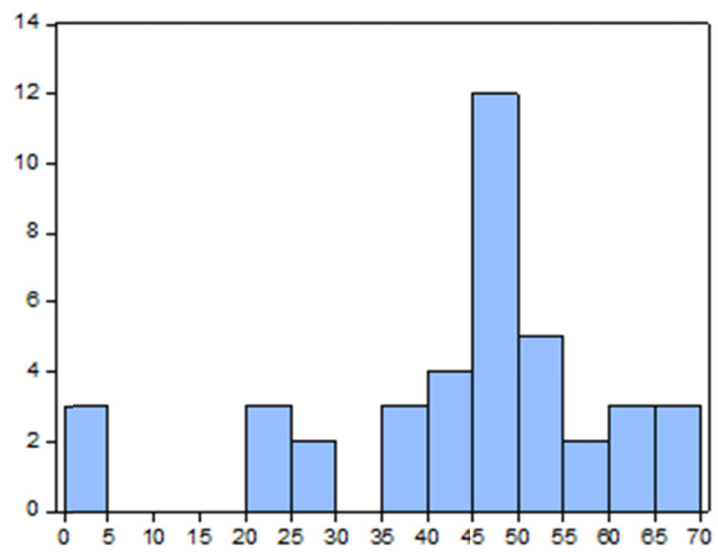

\begin{tabular}{|lr|}
\hline \multicolumn{2}{|l|}{$\begin{array}{l}\text { Series: ELE } \\
\text { Sample 1 40 } \\
\text { Observations }\end{array}$} \\
\hline \\
Mean & 42.67500 \\
Median & 45.50000 \\
Maximum & 69.00000 \\
Minimum & 0.000000 \\
Std. Dev. & 17.00586 \\
Skewness & -1.020266 \\
Kurtosis & 3.882929 \\
& \\
Jarque-Eera & 8.238893 \\
Probability & 0.016254 \\
\hline
\end{tabular}

Figure 1b. CGI in 2011

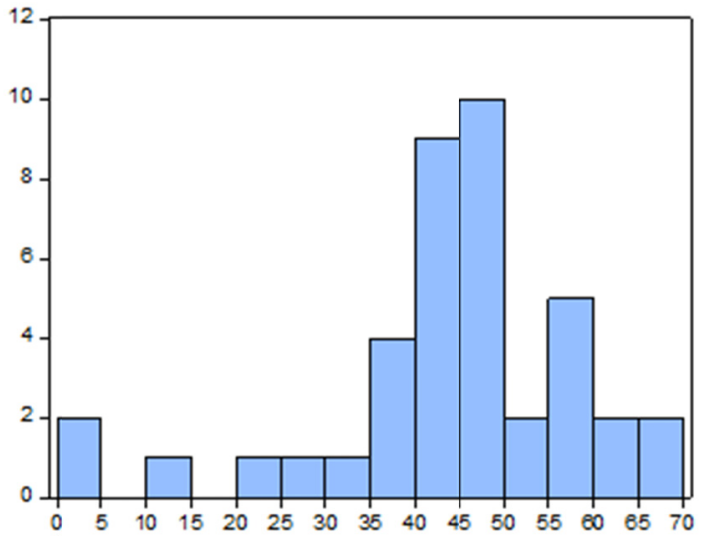

\begin{tabular}{|lr|}
\hline \multicolumn{2}{|l|}{ Series: TLV } \\
Sample 140 \\
\multicolumn{2}{|l|}{ Observations } \\
40 \\
Mean & 43.32500 \\
Median & 45.00000 \\
Maximum & 67.00000 \\
Minimum & 0.000000 \\
Std. Dev. & 14.68540 \\
Skewness & -1.297429 \\
Kurtosis & 5.100087 \\
& \\
Jarque-Bera & 18.57276 \\
Probability & 0.000093 \\
\hline
\end{tabular}

Figure 1c. CGI in 2012

Source: Authors 
The median and standard deviation values also vary very slightly, ranging from 45 to 45.5 and from 14.7 to 17 respectively. Statistical tests confirm that the differences over time are statistically significant.

The maximum values vary between 67 and 69 . Every year, there are always a few banks that do not disclose the necessary information to complete the questionnaire and thus the minimum values are zero $(0)$ in all three years.

The above descriptive statistics indicate that the overall corporate governance situation of Vietnamese banks is consistent over time and do not experience any major positive or negative changes.

\subsection{Results by Listing Status in 2012}

The mean and median CGI for listed banks are considerably higher than those for unlisted banks. Relevant statistical tests reject the null hypothesis of equality, which means the differences are statistically significant.

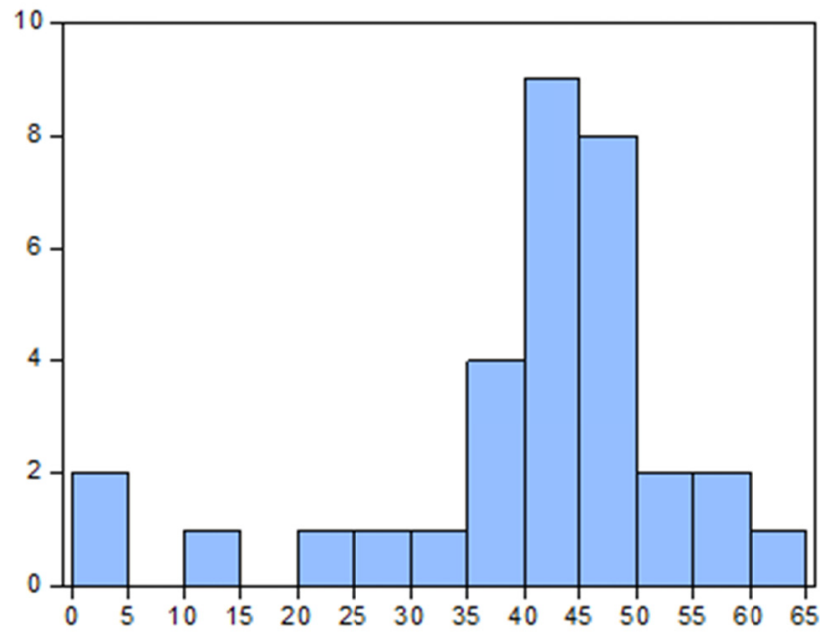

\begin{tabular}{|lr|}
\hline \multicolumn{2}{|l|}{ Series: UNUSTED } \\
Sample 1 32 \\
Observations 32 \\
Mean & 39.81250 \\
Median & 43.00000 \\
Maximum & 60.00000 \\
Minimum & 0.000000 \\
Std. Dev. & 13.98718 \\
Skewness & -1.561927 \\
Kurtosis & 5.193631 \\
& \\
Jarque-Bera & 19.42731 \\
Probability & 0.000060 \\
\hline
\end{tabular}

Figure 2. Histogram and descriptive statistics of CGI series by listing status

Figure 2a. CGI of unlisted banks in 2012

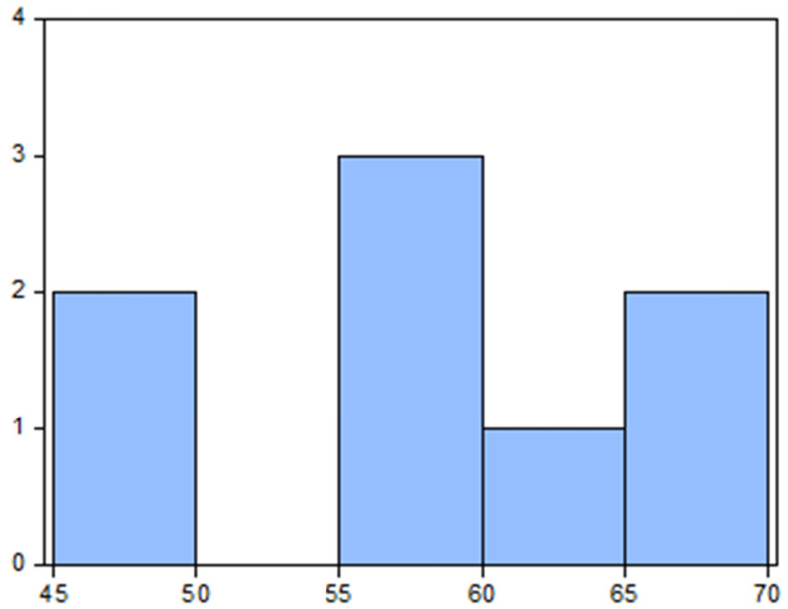

\begin{tabular}{|c|c|}
\hline $\begin{array}{l}\text { Series: UST } \\
\text { Sample } 132 \\
\text { Observation }\end{array}$ & \\
\hline Mean & 57.37500 \\
\hline Median & 57.50000 \\
\hline Maximum & 67.00000 \\
\hline Minimum & 47.00000 \\
\hline Std. Dev. & 7.288690 \\
\hline Skewness & -0.154523 \\
\hline Kurtosis & 1.936713 \\
\hline Jarque-Ber & 0.40869 \\
\hline Probability & 0.81517 \\
\hline
\end{tabular}

Figure 2b. CGI of listed banks in 2012

Source: Authors

Both the minimum and maximum CGI for listed banks are also higher than those for non-listed banks. Notably, the minimum CGI for listed banks is zero (0) while that for non-listed group is 47.

Basically, there are two major reasons explaining why the CGI for the listed group is significantly higher: 
First, listed banks are required by laws and regulations to publicly disclose a variety of information while privately-owned, non-listed banks are not. And thus there is no listed bank getting a CGI of zero (0) due to lack of necessary information to complete the questionnaire while that situation can happen to the non-listed banks.

Second, as pointed out in various researches, listing can really improve the corporate governance quality since companies would have to show sound corporate governance practices to investors in order to attract investments.

\subsection{Results by Size in 2012}

We divided the sample into two groups, the "large" group includes 12 banks with total assets larger than VND100 trillion and the "small" group includes the other 28 banks. As can be seen below, the mean and median of the "large" group are considerably larger than those for the "small" group. To further investigate this characteristic, we run a regression analysis in which CGI is the dependent variable and Total assets is the independent variable. The regression result suggest that the effect of total assets on CGI is positive statistically significant and with every VND1 trillion increase in total assets, the CGI increase by about 0.04 point.

The standard deviation values in both cases are large since the samples are scattered. The maximum values are 60 and 67 while the minimum values are all 0 because both groups have one bank that does not disclose the necessary information to complete the questionnaire.

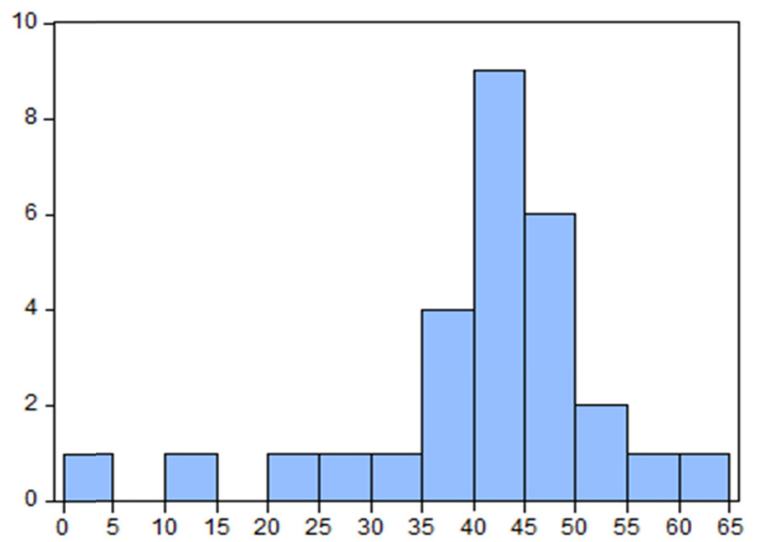

\begin{tabular}{|lr|}
\hline \multicolumn{2}{|l|}{ Series: SMALL } \\
Sample 1 28 \\
Observations 28 \\
Mean & 40.14286 \\
Median & 42.50000 \\
Maximum & 60.00000 \\
Minimum & 0.000000 \\
Std. Dev. & 12.33398 \\
Skewness & -1.536873 \\
Kurtosis & 5.776343 \\
& \\
Jarque-Bera & 20.01532 \\
Probability & 0.000045 \\
\hline
\end{tabular}

Figure 3. Histogram and descriptive statistics of CGI series by assets size

Figure 3a. CGI of small banks in 2012

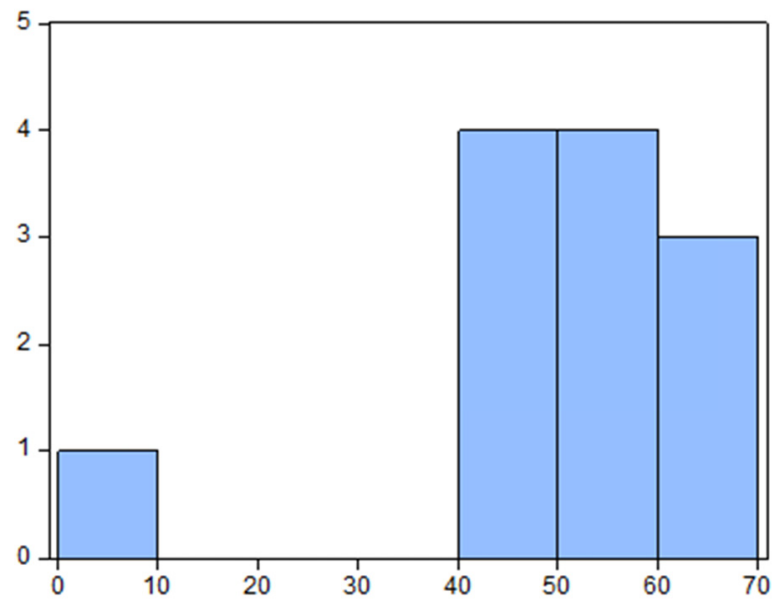

Series: LARGE

Sample 128

Observations 12

Mean

50.75000

Median $\quad 56.00000$

Maximum $\quad 67.00000$

Minimum $\quad 0.000000$

Std. Dev. $\quad 17.47271$

Skewness $\quad-2.160643$

Kurtosis $\quad 7.204973$

Jarque-Bera 18.17765

Probability $\quad 0.000113$

Figure 3b. CGI of large banks in 2012

Source: Authors 


\subsection{Results by Components}

The "role of board of directors" was found to be the weakest among the 4 areas of corporate governance; its CGIs were only 12.6, 13 and 13.3 in 2010, 2011 and 2012 respectively over the maximum score of 34 . Lack of independence is found to be the main problem in corporate governance. The authors conducted in-depth interviews with banks in Ho Chi Minh City in July 2013 and the information obtained also supports this finding. Most of decisions are made by directors and the chairman of banks. Many so-called "independent directors" are in fact not independent. Their decisions are heavily influenced by a group of dominant directors and chairman. This phenomenon is embedded in management in Vietnamese banks partly due to Asian business culture which overemphasize the importance of personal relationship. Moreover, many private banks in Vietnam had been founded by a group of relatives or friends, which means such groups control the overwhelming majority of activities of the banks.

The $2^{\text {nd }}$ weakest area is supervisory board. They are required to be independent of the Board, which helps minimize the conflict of interests. However, many of them are not independent in judging the board and bank performance due to their close relationship with the chairman or CEO. One of the reasons for this problem is the same as for the board of directors problems explained above.

The information disclosure, transparency and shareholders' meeting are all just below average but better than role of board of directors and supervisory board. This finding is supported by our in-depth interviews with banks. Through the interviews, we also found out that the information disclosed is inconsistent and incomparable. Particularly, the information is not transparent because not all investors can access the information on a timely manner. Those having close relationship with banks can get the information earlier than others (mostly small investors). In fact, small investors often invest based on herding behavior so they are even not aware of their rights to information of banks. Moreover, many non-listed banks do not provide financial statements at the end of the period as scheduled.

Table 2. Results by components of the CGI

\begin{tabular}{|c|c|c|c|c|c|c|c|c|c|c|c|c|}
\hline \multirow[b]{2}{*}{$\begin{array}{l}\text { COMPONENT } \\
\text { CGI }\end{array}$} & \multicolumn{4}{|c|}{2010} & \multicolumn{4}{|c|}{2011} & \multicolumn{4}{|c|}{2012} \\
\hline & Min & Max & Average & $\begin{array}{l}\% \text { of } \\
\max \\
\text { score }\end{array}$ & Min & Max & Average & $\begin{array}{l}\% \text { of } \\
\text { Max } \\
\text { score }\end{array}$ & Min & Max & Average & $\begin{array}{l}\% \text { of } \\
\max \\
\text { score }\end{array}$ \\
\hline $\begin{array}{l}\text { I. Shareholders } \\
\text { and General } \\
\text { shareholders'me } \\
\text { eting (Max } \\
\text { Score: } 37 \text { ) }\end{array}$ & 0 & 30 & 17.8 & 48.0 & 0 & 28 & 18.2 & 49.1 & 0 & 27 & 18.72 & 50.6 \\
\hline $\begin{array}{l}\text { II. Board of } \\
\text { Directors - CGI } \\
2 \text { (Max } \\
\text { score:34) }\end{array}$ & 0 & 20 & 12.6 & 36.91 & 0 & 20 & 13 & 38.2 & 0 & 20 & 13.3 & 39.1 \\
\hline $\begin{array}{l}\text { III. Supervisory } \\
\text { Board (Max } \\
\text { score: } 8 \text { ) }\end{array}$ & 0 & 6 & 3.4 & 42.8 & 0 & 7 & 3.6 & 45 & 0 & 7 & 3.87 & 48.4 \\
\hline $\begin{array}{l}\text { IV. Information } \\
\text { disclosure, } \\
\text { transparency } \\
\text { and audit (Max } \\
\text { score: } 21 \text { ) }\end{array}$ & 0 & 16 & 9.9 & 47.1 & 0 & 16 & 10.1 & 48.2 & 0 & 14 & 9.28 & 44.2 \\
\hline $\begin{array}{l}\text { V. Violation } \\
\text { (Max: 0) }\end{array}$ & -2 & 0 & -0.4 & & -2 & 0 & -0.48 & & -2 & 0 & -0.67 & \\
\hline CGI (Max: 100) & 0 & 68 & 43.3 & 43.3 & 0 & 69 & 44.9 & 44.9 & 0 & 67 & 44.5 & 44.5 \\
\hline
\end{tabular}




\section{Conclusion}

This paper has proposed a method to build the Corporate Governance Index to measure the quality of corporate governance of 40 Vietnamese banks.

A detailed questionnaire with 60 questions divided into 5 categories: Shareholders and general shareholders' meeting; Board of directors; Supervisory board; Disclosure and transparency, auditing and Violations has been prepared. This questionnaire was completed using public information gathered from banks' annual reports, financial reports, GSM minutes, websites and other sources.

Statistical analysis of the results obtained suggests that the quality of corporate governance in Vietnamese bank over three years 2010, 2011 and 2012 are stable and below the medium level with the CGI ranging from 41 to 44 over 100. The results by listing status of the banks expectedly show that listed banks have better corporate governance practices and thus significantly higher CGI. And finally, the results by assets size indicate that big banks tend to have better quality of corporate governance than smaller banks.

The above result also supports finding of qualitative assessment of corporate govrenance for firms and banks by Nguyen Dinh Cung (2006), Tran Thi Thanh Tu and Pham Bao Khanh (2011, 2012). Therefore, this result can provide initial justification for the the proposed CGI construction methodology

Future studies to investigate the relationship between corporate governance and banks value or banks performance can be carried out based on the CGI constructed in this paper.

\section{References}

Ananchotikul, Nasha. (2008). Does Foreign Direct Investment Really Improve Corporate Governance? Evidence from Thailand. Bank of Thailand Discussion Paper DP/03/2008.

Basel Committee on Banking Supervision (BCBS), (2010). Principles for Enhancing Corporate Governance, Switzerland.

Bebchuk, L., Cohen, A., \& Ferrell, A. (2008, February). What Matters in Corporate Governance? Review of Financial Studies, 22(2), 783-827.

Cheung, Y. L., Connelly, J. T., Limpaphayom P., \& Zhou L. (2005). Do Investors Really Value Corporate Governance? Evidence from the Hong Kong Market. HKIMR Working Paper No.22/2005, Hong Kong Institute ForMonetary Research.

Financial Stability Board (FSB). (2009). Principles for Sound Compensation Practices.

Kumar, P., \& Upadhyaya, P. T. (2011, September). Corporate governance index formulation: compliance with commercial banks of Nepal. International Journal of Multidisciplinary Research, 1(5).

Love, I., \& Rachinsky, A. (2007). Corporate Governance, Ownership and Bank Performance in Emerging Markets: Evidence from Russia and Ukraine. Working paper.

Manawaduge, A. (2012). Corporate governance practices and their impacts on corporate performance in an emerging market: the case of Sri Lanka. Doctor of Philosophy thesis, School of Accounting and Finance, University of Wollongong, 2012. Retireved from http://ro.uow.edu.au/theses/3676

Monda, B., \& Giorgino, M. (2013). Corporate Governance and Shareholder Value in Listed Firms: An Empirical Analysis in Five Countries (France, Italy, Japan, UK, USA). DIG, Politecnico di Milano, MPRA Paper No. 45429.

OECD. (2004). OECD Principles of Corporate Governance. OECD Publications, Paris.

Quach Manh Hao. (2008). Equalization in Vietnam: Corporate governance perspective.

Ramlal V. L. (2011). A Framework for the Construction of a Corporate Governance Index for Trinidad \& Tobago. Retireved from http://sta.uwi.edu/conferences/09/salises/documents/V\%20ramlal.pdf

Sarkar, Jayati, Sarkar, Subrata, \& Sen, Kaustav. (2012). A Corporate Governance Index for Large Listed Companies in India, Indira Gandhi Institute of Development Research. Retireved from http://ssrn.com/abstract=2055091

T.N.Thang. (2010). Building corporate governance index. State research project.

Tuteja, Sumedha, \& Nagpal C.S. (2013). Formulation of Corporate Governance Index for Banks in India. Research Journal of Finance and Accounting, 4(7). 
Appendix 1. The questionnaire designed and used in this research

\begin{tabular}{|c|c|c|}
\hline No. & Description & Points \\
\hline I & Shareholders and General Shareholders' Meeting & \\
\hline 1 & If there are shares held by foreign individual and institutional investors & 1 \\
\hline 2 & If the bank has intention and plan to go listed (For unlisted banks) & 1 \\
\hline 3 & If the bank has plan to be listed on international market & 1 \\
\hline 4 & The benchmark of proportion of shares a for large shareholder is $5 \%$. & 1 \\
\hline 5 & Shareholders can transfer their shares to others without restriction & 1 \\
\hline 6 & The bank's charter is fully complied with central bank regulations & 1 \\
\hline 7 & $\begin{array}{l}\text { The bank's governance policies include: } \\
\text { - Procedure to convene and vote General shareholders' meeting. } \\
\text { - Procedure to propose, nominate and terminate BOD members. } \\
\text { - Procedure to convene BOD meetings. } \\
\text { - Procedure to nominate and terminate executive positions. } \\
\text { - Performance evaluation and bonus policy for governance units of the bank }\end{array}$ & $\begin{array}{l}1 \\
1 \\
1 \\
1 \\
1 \\
1\end{array}$ \\
\hline 8 & 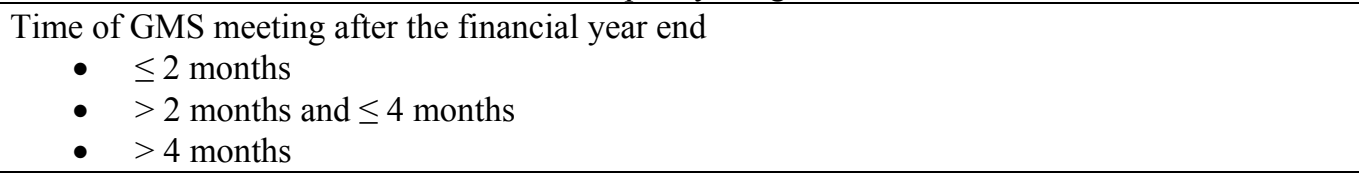 & $\begin{array}{l}2 \\
1 \\
0\end{array}$ \\
\hline 9 & $\begin{array}{l}\text { Invitation for GMS meeting is sent prior to date of meeting: } \\
\text { - } \quad \leq 10 \text { days } \\
\text { - } \quad 11 \text { days }-20 \text { days } \\
\text { - }>21 \text { days }\end{array}$ & $\begin{array}{l}0 \\
1 \\
2\end{array}$ \\
\hline 10 & $\begin{array}{l}\text { If the bank does not have a minimum requirement for numbers of shares held by investors for } \\
\text { shareholders to be eligible to attend the meeting }\end{array}$ & 1 \\
\hline 11 & $\begin{array}{l}\text { Information about GSM meeting is conveyed to shareholders by } \\
\text { - Letter to shareholders } \\
\text { - Website } \\
\text { - Newspapers }\end{array}$ & $\begin{array}{l}1 \\
1 \\
1\end{array}$ \\
\hline 12 & The bank has guidelines and policy for GSM & 1 \\
\hline 13 & $\begin{array}{l}\text { The bank provides information about voting procedures and rules: } \\
\text { - To shareholders } \\
\text { - Public media } \\
\text { - Both }\end{array}$ & $\begin{array}{l}1 \\
1 \\
2\end{array}$ \\
\hline 14 & Shareholders can vote through their representatives & 1 \\
\hline 15 & Accumulative voting is applied in GSM & 1 \\
\hline 16 & $\begin{array}{l}\text { Reports of the board of directors include: } \\
\text { - Report on bank operation and performance } \\
\text { - Report on supervision of bank operation and financial conditions. } \\
\text { - } \quad \text { Report on supervision of BOM and executive staff } \\
\text { - } \quad \text { Others }\end{array}$ & $\begin{array}{l}1 \\
1 \\
1 \\
1 \\
1\end{array}$ \\
\hline 17 & $\begin{array}{l}\text { Reports by supervisory board at GSM include: } \\
\text { - Operation and performance of supervisory board } \\
\text { - } \text { Meeting results and decisions of supervisory board } \\
\text { - Report on supervision of operation and financial conditions of the bank } \\
\text { - } \text { Evaluation of the cooperation among BOD, supervisory board, BOM and shareholders } \\
\text { - Others }\end{array}$ & $\begin{array}{l}1 \\
1 \\
1 \\
1 \\
1 \\
1\end{array}$ \\
\hline 18 & GSM's resolution are published on the bank website & 1 \\
\hline II & & \\
\hline
\end{tabular}


19 The ratio of non-executive and independent directors to total BOD members is:

- $1 / 2$

- $>1 / 2$

20 Number of independent directors:

- $\leq 2$

- $>2$

21 Information on qualification, training and experience of BOD members is:

- Published on website or on public media

- Informed in GSM

- Both on website or public media and GSM

- Not disclosed

22 Chairman is independent director

23 BOD has following committees:

- HR committee and Risk management committee

- $\quad$ HR committee, Risk management committee, others

1

he bank has following procedures:

- Selection, nomination and termination of BOD members

- Selection, nomination and termination of executive officers.

25 Profile of BOD candidates are notified to shareholders prior to the GSM

26 BOD member has informed their commitment of integrity, accuracy and relevance of information provided

$27 \quad$ Term of board members are not the same

28 Minutes and resolution of BOD is published

29 There is published information which help evaluate competency and independence of member of audit committee or internal audit department

\begin{tabular}{|c|c|c|}
\hline 30 & The bank has its secretary or secretariat to BOD & 1 \\
\hline 31 & $\begin{array}{l}\text { The requirement of shares held by a shareholder to become BOD candidate is } 5 \% \text { and less than } \\
\text { that. }\end{array}$ & 1 \\
\hline 32 & The bank has code of ethics & 1 \\
\hline 33 & Performance of BOD members are evaluated & 1 \\
\hline 34 & $\begin{array}{l}\text { The bank has: } \\
\text { - Back up personnel plan } \\
\text { - Disclosed number of board meetings in a year } \\
\text { - Disclosed attendance of BOD members in the year } \\
\text { - Disclosed responsibilities of each board member } \\
\text { - } \text { Provided training to board member } \\
\text { - } \text { Buy insurance of responsibility for board member }\end{array}$ & $\begin{array}{l}1 \\
1 \\
1\end{array}$ \\
\hline
\end{tabular}

35 Remuneration for board member is based on:

- Financial performance

- Behaviors in fulfilling their duties

(n)

- Both financial performance and behaviors

36 BOD is independent in deciding management's remuneration.

37 Remuneration for BOD is:

- Cash

- Common share

- $\quad$ Preferred share

38 The bank discloses the following information in GSM:

- The whole remuneration for BOD

1

- Remuneration of each member

- Plan for the coming year's remuneration

1

1

1

1

1

1

\begin{tabular}{lll}
\hline III & Supervisory board & \\
\hline 39 & There is information for shareholders to evaluate training background and experience of & 1 \\
\hline
\end{tabular}


supervisory board members.

\begin{tabular}{lll}
\hline 40 & Supervisory board members have commitment of business ethics & 1 \\
\hline 41 & Supervisory board has their own procedure in order to implement their duties independently & 1 \\
\hline 42 & The bank has procedure and policy in nominating and terminating supervisory board members. & 1 \\
\hline 43 & Supervisory board has their own operation policy. & 1 \\
\hline 44 & The number of meetings per annum of supervisory board is disclosed & 1 \\
\hline 45 & Supervisory board members are paid based on their performance & 1 \\
\hline 46 & The bank provides training to supervisory board members. & 1 \\
\hline IV & Disclosure and transparency, auditing & 1 \\
\hline 47 & The bank prepares financial reports based on: & 1 \\
& $\bullet \quad$ Vietnam accounting standard & 2 \\
& $\bullet \quad$ International accounting or reporting standard & \\
\hline
\end{tabular}

48 The bank discloses:

- Unaudited financial reports quarterly and yearly

- Audited annual financial reports

- Consolidated reports and bank reports

- Annual report

- Internal transactions

- Third party transactions

49 The bank has disclosed financial reports

- Monthly, quarterly, annually

- Quarterly, annually

$50 \quad$ The bank discloses financial reports and annual report on time as specify by central bank

51 The bank gives explanation for late disclosure of above reports

52 The bank gives explanation for differences (if any) between unaudited financial report and audited financial report.

53 The bank has :

- its own website and updated continuously

- in English

54 Communication with shareholders is done through:

- Shareholders' newsletter

- Shareholders' meeting

- Others

\begin{tabular}{lll}
\hline 55 & The external auditor is among big four (E \& Y, PWC, KPMG, Deloitte Vietnam) & 1 \\
\hline 56 & The bank has procedure for selecting external auditor & 1 \\
\hline 57 & The bank has policy to change external auditor & 1 \\
\hline 58 & The bank actually changes external auditors at least every 5 years & 1 \\
\hline $\mathbf{V}$ & Violations & -1 \\
\hline 59 & There is evidence for violation related to information disclosure & -1 \\
\hline 60 & There is evidence for violation related to audit
\end{tabular}


Appendix 2. Test for equality

\section{- Test for equality of means between CGI series by years 2010, 2011, 2012}

Test for Equality of Means Between Series

Date: 12/11/13 Time: 12:12

Sample: 140

Included observations: 40

\begin{tabular}{lcrr}
\hline \hline Method & df & Value & Probability \\
\hline \hline Anova F-test & $(2,117)$ & 0.074559 & 0.9282 \\
Welch F-test* & $(2,77.7121)$ & 0.079408 & 0.9237 \\
\hline \hline
\end{tabular}

*Test allows for unequal cell variances

Analysis of Variance

\begin{tabular}{lrrr}
\hline \hline Source of Variation & df & Sum of Sq. & Mean Sq. \\
\hline \hline Between & 2 & 37.85000 & 18.92500 \\
Within & 117 & 29697.45 & 253.8244 \\
\hline \hline Total & 119 & 29735.30 & 249.8765 \\
\hline \hline
\end{tabular}

\section{- Test for equality of means between CGI series by listing status}

Test for Equality of Means Between Series

Date: 11/30/13Time: $22: 21$

Sample: 131

Included observations: 31

\begin{tabular}{lrrr}
\hline \hline Method & df & Value & Probability \\
\hline \hline t-test & 38 & 3.717235 & 0.0006 \\
Satterthwaite-Welch t-test* & 27.98795 & 5.306598 & 0.0000 \\
Anova F-test & $(1,38)$ & 13.81784 & 0.0006 \\
Welch F-test* & $(1,27.9879)$ & 28.15998 & 0.0000 \\
\hline \hline
\end{tabular}

*Test allows for unequal cell variances

Analysis of Variance 


\begin{tabular}{lcrr} 
Source of Variation & df & Sum of Sq. & Mean Sq. \\
\hline \hline Between & 1 & 2242.832 & 2242.832 \\
Within & 38 & 6167.943 & 162.3143 \\
\hline \hline Total & 39 & 8410.775 & 215.6609 \\
\hline \hline
\end{tabular}

\section{- Test for Equality of Means between CGI series by assets size}

Test for Equality of Means Between Series

Date: $12 / 11 / 13$ Time: $12: 11$

Sample: 135

Included observations: 35

\begin{tabular}{lrrr}
\hline \hline Method & df & Value & Probability \\
\hline \hline t-test & 38 & -2.193286 & 0.0345 \\
Satterthwaite-Welch t-test* & 15.90436 & -1.908970 & 0.0745 \\
Anova F-test & $(1,38)$ & 4.810502 & 0.0345 \\
Welch F-test* & $(1,15.9044)$ & 3.644168 & 0.0745 \\
\hline
\end{tabular}

*Test allows for unequal cell variances

Analysis of Variance

\begin{tabular}{lccr}
\hline \hline Source of Variation & df & Sum of Sq. & Mean Sq. \\
\hline \hline Between & 1 & 945.0964 & 945.0964 \\
Within & 38 & 7465.679 & 196.4652 \\
\hline \hline Total & 39 & 8410.775 & 215.6609 \\
\hline \hline
\end{tabular}

